\title{
Is useful the visual estimate of transmurality of hipoperfusión in stress cardiac magnetic resonance?
}

\author{
Begoña M Igual Sr${ }^{1 *}$, Sanchez G Juan Miguel ${ }^{2}$, Buendia S Francisco ${ }^{3}$, Lopez Lereu Pilar ${ }^{1}$, Monmeneu M JV', \\ IEJ Estornell ${ }^{1}$, Maceira G Alicia ${ }^{1}$
}

From 2011 SCMR/Euro CMR Joint Scientific Sessions

Nice, France. 3-6 February 2011

\section{Introduction}

With dipyridamol stress cardiac magnetic resonance imaging (DSCMR), we obtain high spatial resolution images that allow us to assess the transmurality of hypoperfusion but the clinical usefulness of this information has not been evaluated.

\section{Purpose}

We aimed to asses the usefulness of visual estimate of transmurality in relation to the coronary tree

\section{Methods}

We reviewed the CMR data base (2008-2009) to obtain data from patients with positive DSCMR and medical records to know the coronary tree. We visually asses transmurality of hypoperfusion in each of the 17 segments in all patients studied and hypoperfusion was classified as $>$ or $<50 \%$ of the segment area.

\section{Results}

We studied, 112 consecutive patients 108 of them had performed. coronary angiography, 66 males(61\%), Mean age $66 \pm 10$ years $5(4.6 \%)$ without significant coronary lesions (PPV: 95\%). Patients with hypoperfusion $>50 \%$ in any segment (79 patients $73 \%$ ) had a number significantly higher of affected vessels $(2 \pm 0,8$ vs $1,6 \pm 0,9 \mathrm{p}=0.04)$, greater number of segments with systolic dysfunction induced (SDI) $((3,6 \pm 2,3$ vs $0,06 \pm 0,3 p<0.001)$ and greater number of territories affected $1,7 \pm 0,7$ vs $1,4 \pm 0,6 \mathrm{p}=0.04)$. The number of segments with hypoperfusion $>50 \%$ was significantly higher in patients with SDI ( $5.9 \pm 2,4$ vs $2,4 \pm 3 \mathrm{p}=0.02$ )

${ }^{1}$ Eresa, Valencia, Spain

Full list of author information is available at the end of the article

\section{Conclusions}

1.the presence of hypoperfusión $>50 \%$ indicates greater severity of coronary artery disease (CAD) with more vessels and territories afected.2.The number of segments with severe hypoperfusion is higher in patients with systolic dysfunction induced. 3 . The transmurality of hypoperfusion is an indicator of severity of CAD and should be reported routinely

\section{Author details}

'Eresa, Valencia, Spain. ${ }^{2}$ Hospital La Fe., VALENCIA, Spain. ${ }^{3}$ Hospital la Fe, VALENCIA, Spain.

Published: 2 February 2011

doi:10.1186/1532-429X-13-S1-P109

Cite this article as: Igual et al:: Is useful the visual estimate of

transmurality of hipoperfusión in stress cardiac magnetic resonance?. Journal of Cardiovascular Magnetic Resonance 2011 13(Suppl 1):P109.

Submit your next manuscript to BioMed Central and take full advantage of:

- Convenient online submission

- Thorough peer review

- No space constraints or color figure charges

- Immediate publication on acceptance

- Inclusion in PubMed, CAS, Scopus and Google Scholar

- Research which is freely available for redistribution

Submit your manuscript at www.biomedcentral.com/submit 